\title{
Modification of Lithium Iron Phosphate by Carbon Coating
}

\author{
Zheng Zhang, Mingming Wang, Junfeng Xu, Fangchang Shi, Meng Li and Yanmin Gao* \\ School of Materials Science and Engineering, Jiangsu University of Science and Technology, Jiangsu, \\ Zhenjiang 212003, China \\ *E-mail: 1571539864@qq.com
}

doi: $10.20964 / 2019.11 .22$

Received: 9 June 2019 / Accepted: 15 August 2019 / Published: 7 October 2019

\begin{abstract}
Lithium Iron Phosphate $\left(\mathrm{LiFePO}_{4}\right)$ for lithium-ion batteries is considered as perfect cathode material for various military applications.Carbon coating has a great influence on the properties of lithium iron phosphate. In this paper, the effects of in-situ carbon coating and non-in-situ carbon coating on the structure and properties of lithium iron phosphate were analyzed.For $\mathrm{LiFePO}_{4} / \mathrm{C}$ synthesized by carbon coating, no matter it is non-in-situ coating or in-situ coating, it can improve the electrochemical performance of $\mathrm{LiFePO}_{4}$. In this paper, ascorbic acid was used as the carbon source, and the sample coating layers formed by in-situ carbon coating and non-in-situ carbon coating were $10 \mathrm{~nm}$ and $20 \mathrm{~nm}$ respectively. Through the electrochemical measurements, In situ carbon coated and non-in-situ carbon coated lithium iron phosphate, the specific capacity of charge and discharge for the first time reached $125 \mathrm{mAh} \cdot \mathrm{g}^{-1}$ and $112 \mathrm{mAh} \cdot \mathrm{g}^{-1}$ respectively at the rate of $0.1 \mathrm{C} .$. Meanwhile, comparing the two coating methods, The structure and properties of in-situ carbon coating are better than those of non-in-situ carbon coating.
\end{abstract}

Keywords: lithium iron phosphate, In situ carbon coating, Non-in-situ carbon coating, electrochemical performance

\section{$\underline{\text { FULL TEXT }}$}

(C) 2019 The Authors. Published by ESG (www.electrochemsci.org). This article is an open access article distributed under the terms and conditions of the Creative Commons Attribution license (http://creativecommons.org/licenses/by/4.0/). 